\title{
MORPHOLOGICAL CHANGES OF THE GASTRIC MUCOSA WHILE USING ANTIAGGREGANTS AND PANTOPRAZOLE (AN EXPERIMENTAL STUDY)
}

D0I:10.36740/WLek202102110

\author{
Alla G. Yankovetska, Serhii V. Vernyhorodskyi, Iryna G. Paliy, Serhii V. Zaika \\ NATIONAL PIROGOV MEMORIAL MEDICAL UNIVERSITY, VINNYTSIA, UKRAINE
}

\begin{abstract}
The aim: Was to characterize the morphological peculiarities of the gastric mucosa at early stage of prescription of acetylsalicylic acid (ASA) and clopidogrel as well as to study the impact of pantoprazole on the gastric mucosa to optimize the prophylaxis and treatment of gastropathies induced by ASA and clopidogrel.

Materials and methods: The experiments were performed on 77 non-linear white male rats with the average weight of 150-180 g. Depending on the aim of research, the animals were divided into 7 groups.

Results: The administration of pantoprazole in combination with ASA and clopidogrel presented positive trends in neutral glycoproteins amount and contributes to preventing GM necrotic lesions by amplification of protective properties of mucus and stabilization of apoptotic activity of gastric epithelial cells.

Conclusions: 1. According to our study findings, administration of ASA in combination with clopidogrel results in 2,5 times higher risk of GM erosive lesions.

2. One of the most significant morphological manifestations of gastropathy in ASA and clopidogrel regimen is the development of microerosions, which are poorly diagnosed by macroscopic examination.

3. The use of PAS-reaction makes possible to identify damage to the basal membrane of superficial epitheliocytes, which may be a top-priority morphological criterion of gastropathy induced by ASA or clopidogrel in the absence of an inflammatory reaction.

4. Administration of pantoprazole in combination with ASA and clopidogrel contributes to preventing GM necrotic lesions by amplification of protective properties of mucus and stabilization of apoptotic activity of gastric epithelial cells.
\end{abstract}

KEY WORDS: acetylsalicylic acid, clopidogrel, pantoprazole, morphological changes, stomach erosive lesions

Wiad Lek. 2021;74(2):228-235

\section{INTRODUCTION}

The use of nonsteroidal anti-inflammatory drugs (NSAIDs) remains extremely actual in treating pain, inflammation in antiplatelet therapy. These remedies belong to the preparations most widely used in the practice of doctors of different specialties $[1,2]$.

The consequence of such a wide, sometimes incontrollable, taking preparations is a high frequency of complications which emerge due to the damage of the gastrointestinal tract (GIT) and got the name of the NSAIDs gastropathies. [3 ]

One of the most widely spread representatives of inflammatory preparations is acetylsalicylic acid (ASA). ASA used in low (antiplatelet) doses remains by now a rather effective and cheap remedy of the profilaxis of vascular catastrophes linked to IHD and atherosclerosis [4].

At the same time, there exist a number of limitations for the indication of ASA and this is, first of all, the development of erosive ulcerative lesions of the stomach. The risk factors of the emergence of gastropathy are: peptic ulcer of the stomach and duodenum, the age over 60 , taking other preparations (glucocorticoids, anticoagulants NSAIDs), etc.
Thus, in persons with ulcerative diseases, who take ASA, the frequency of the development of gastrointestinal bleeding (GIB) increases by 3 times. The use of NSAIDs in combination with ASA raises the probability of the emergence of GIB approximately by 4 times as compared to ASA monotherapy. Simultaneously, the indication of ASA during 26 weeks together with PPIs, for example, esomeprazol with the dose of $20 \mathrm{mg}$ per 24 hours, decreased the risk of the stomach and duodenum ulcers development from 5,4 to $1,6 \%[5,6]$.

In 2002, in the manual issued by the American College of Cardiology (ACC) and American Heart Association (AHA), it was noted that in case of the impossibility of ASA application as a consequence of its negative impact on the GIT, one should use clopidogrel.

The recommendation like this was shaped on the basis of the CARPIE research, in which they compared the effects of ASA $(325 \mathrm{mg} / 24 \mathrm{~h})$ and clopidogrel $(75 \mathrm{mg} / 24 \mathrm{~h})$ in patients with the risk of ischemic events .In both groups, the frequency of GIB was low: in the ASA - 0,72\%, in the clopidogrel $-0,52 \%$, However, it was concluded that the latter had some advantages $[7,8,9]$.

Nevertheless, the subsequent researches with the more 


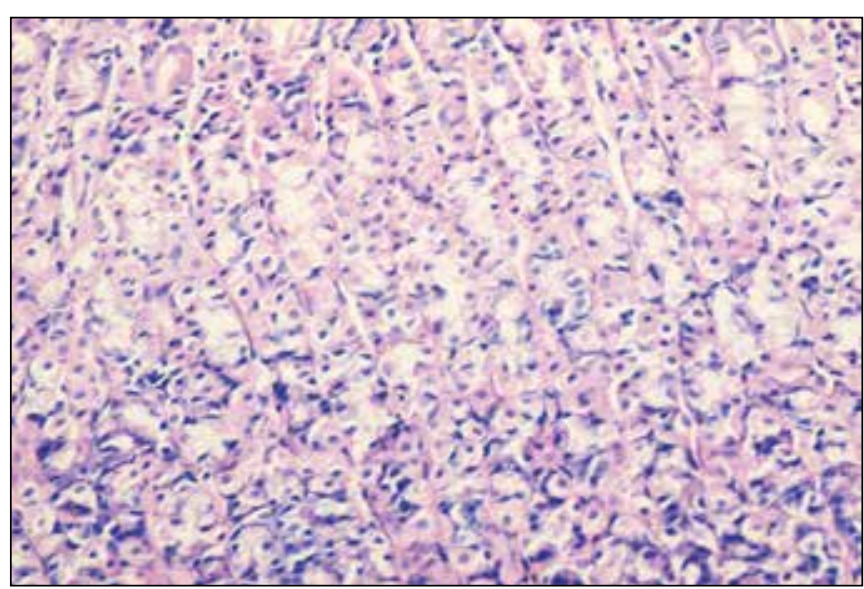

Fig. 1. The mucosa of the fundic part of the rat stomach (control group, the 14th day). The histological structure of the GM is preserved with the distinct differentiated location of the fundic glands' cells. Staining with hematoxyllin and eosin $x 100$.

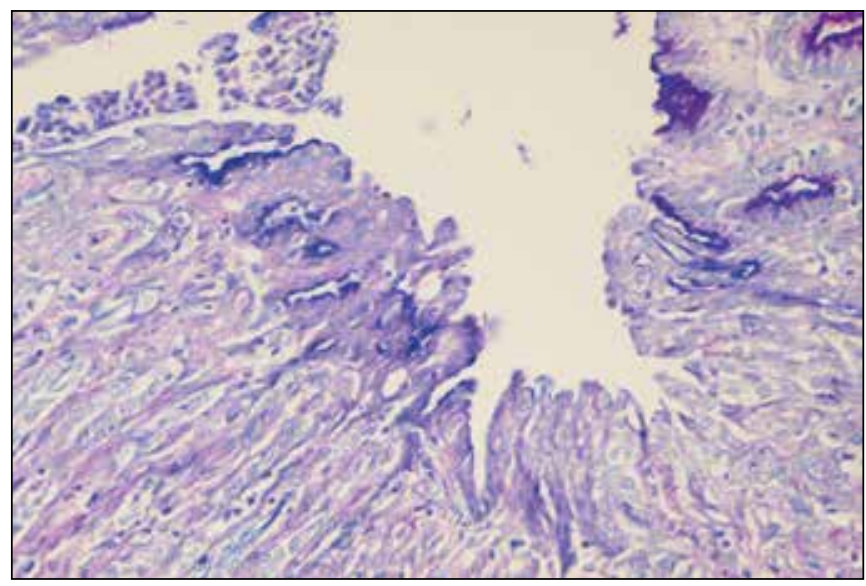

Fig. 3. Superficial erosion of antral part GM rat. Desquamative epithelium, the absence of neutral glycoproteins, an unsignificant number of acid sialomucins (blue color). ASA, 14 day. Combined PAS-reaction and alcian blue $x 400$.

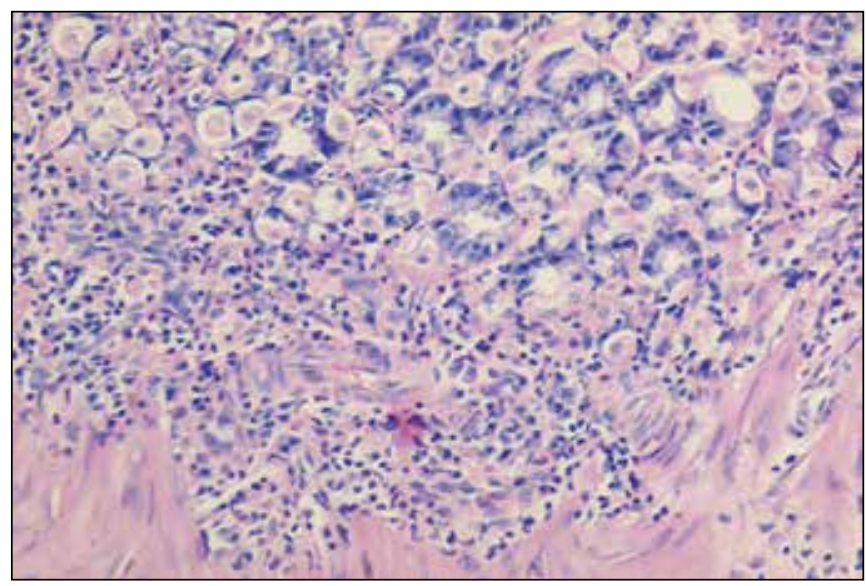

Fig. 5. The dissociation of parietal and chief exocrinocytes in the basal parts of GM. Staining with hematoxyllin and eosin x 400 .

detailed design proved the ulcerogenic effect of antiaggregants. In the case-control study, which included $2777 \mathrm{pa}-$ tients with expressed GIB and 5532 patients of the control

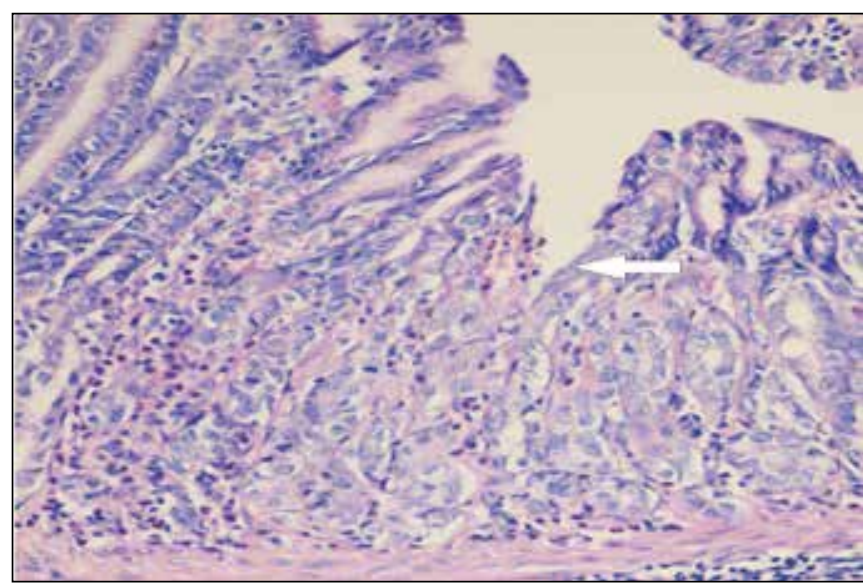

Fig. 2. Superficial erosion of the rat's GM antral part (arrow). Minute haemorrhage, single leukocytes. ASA, 14 day. Staining with hematoxyllin and eosin $\times 200$.

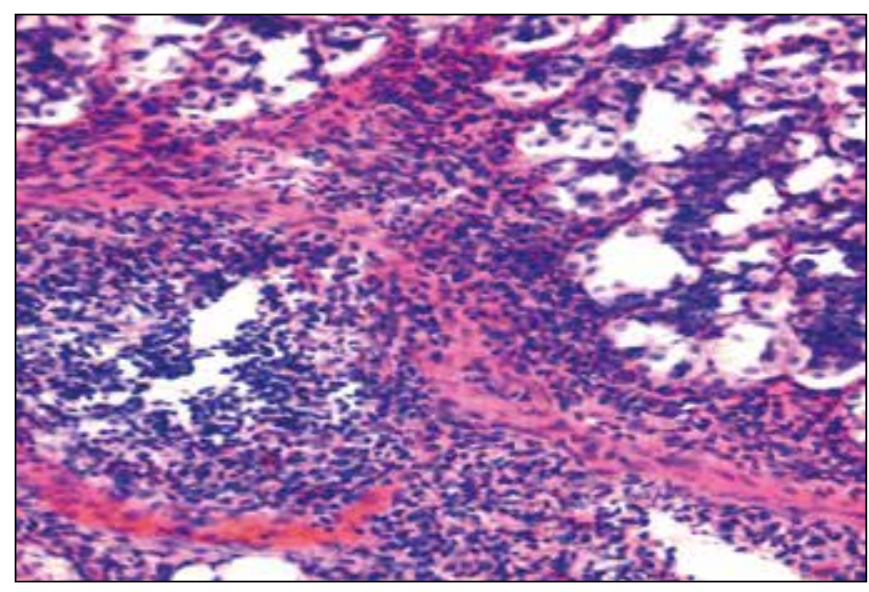

Fig. 4. The focal lympho- and plasmocytic infiltration of the GM muscular lamina. ASA, 14 days. Staining with hematoxyllin and eosin x 400 .

group, it was stated that clopidogrel and ticlopidine have a comparable relative risk equal to 2,8 in relation to ASA and anticoagulants [10].

Antiaggregants are as dangerous as low doses of ASA as for the risk of GIB development. It is better to prescribe low doses of ASA with PPIs rather than clopidogrel to patients with high GIB risk [11].

Low doses of ASA used as an antiaggregant remedy in cardiovascular diseases (CVD) can also cause the development of serious gastroduodenal complications. In 30-40\% of the patients, who took ASA in the minimum dose of 75 $\mathrm{mg} / 24 \mathrm{~h}$, gastric erosions emerged. After the literature in question data, the use of ASA in such a dose doubles the risk of GIB $[12,13]$.

The leading role in the treatment of NSAIDs gastropathies is played by antisecretory preparations which reduce the damaging effect of the hydrochloric acid and pepsin which is the main factor of aggression in the pathogenesis of the ulcerative and erosive damage to the mucosa of the upper parts of the GIT.

The best results on tolerance among PPIs are demonstrated by pantoprazole: in its application, insignificant side effects are recorded just in $1,1 \%$ patients $[14,15]$. 


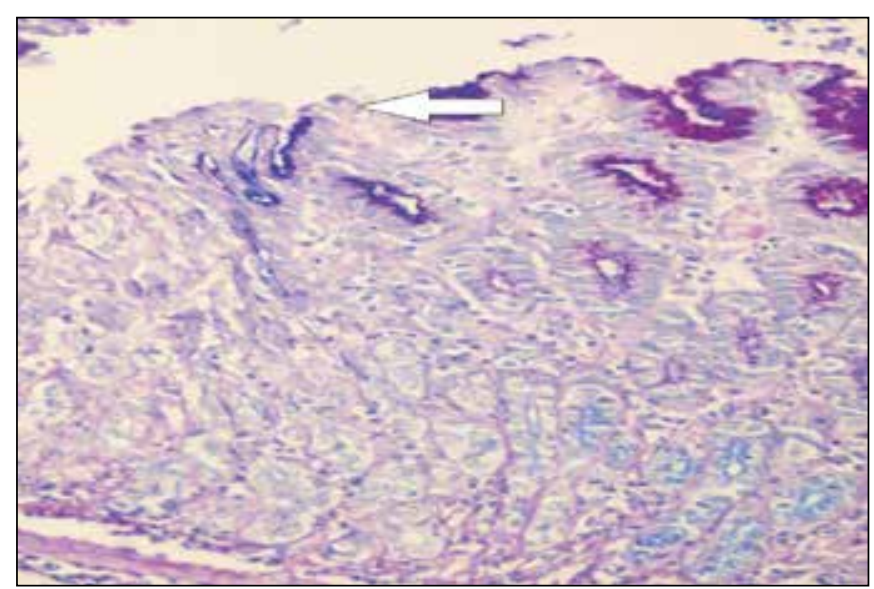

Fig. 6. Superficial erosion of the antral part GM. The basement membrane is absent in the area of damage (marked by an arrow) and preserved in the foci of neutral mucins accumulation (crimson colour). ASA, 14 days. Combined PAS-reaction-alcian blue x 400 .

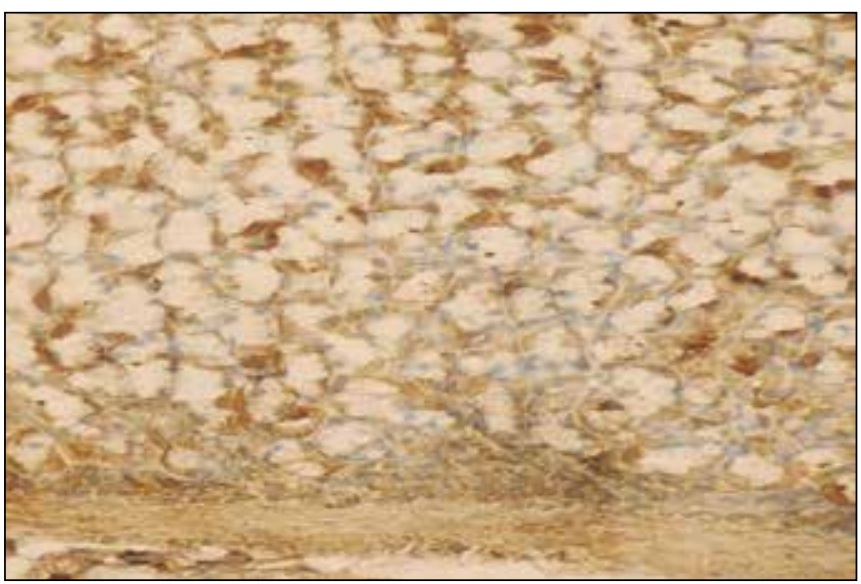

Fig. 8. The moderate expression of CPP32 in perinuclear parts of fundic glands exocrinocytes. Clopidogrel + pantoprazole, 14day. Immunohistochemical reaction CPP32 x 200.

The modern diagnostics of NSAIDs gastropathies represents an unsolved finally problem connected to the peculiarities their clinic manifestations. For $30-90 \%$, their asymptomatic course is characteristic, while for $46-58 \%$ the absence of typical and expressed clinical picture and in $25-42 \%$ patients symptoms of the basic diseases prevail. As a consequence of this, NSAIDs gastropathies often remain undiagnosed till they appear as bleeding not rarely dangerous for life.

That is, the problem of NSAIDs' application in the form of monotherapy or in combination with other groups of antiaggregants in patients with cardio-vascular diseases (CVD) has not been solved eventually by now.

The correlation of aggressive factors of gastric contents and protective systems of gastric mucosa (GM) in the application of ASA and clopidogrel are still little studied.

The morphological criteria of the gastropathies induced by ASA and clopidogrel need further research. Hence, the specification of NSAIDs-induced gastropathies' mechanisms and the search of effective ways of their prophylaxes and treatment are actual.

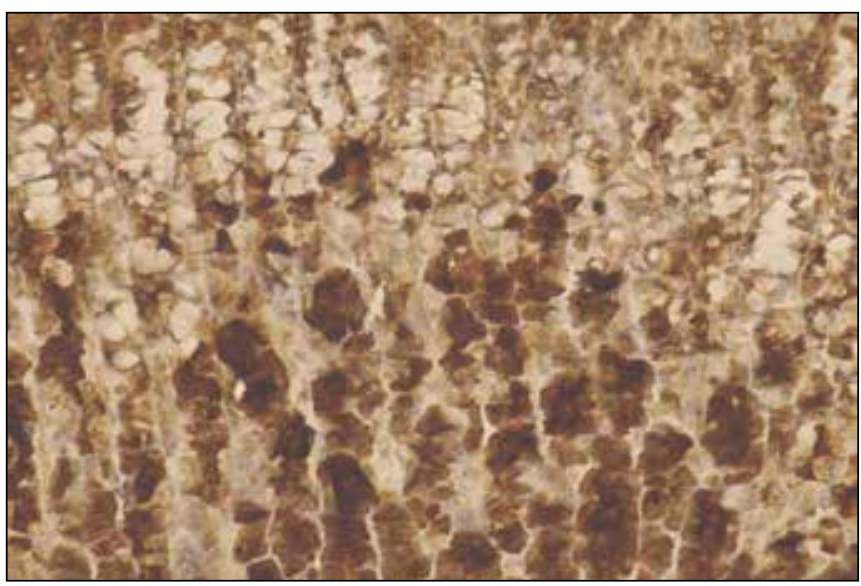

Fig. 7. A strong expressionofcaspase-3 (CPP32), mainly in the basal parts of GM. ASA + clopidogrel, 14day. Immunohistochemical reaction CPP32 $\times 200$.

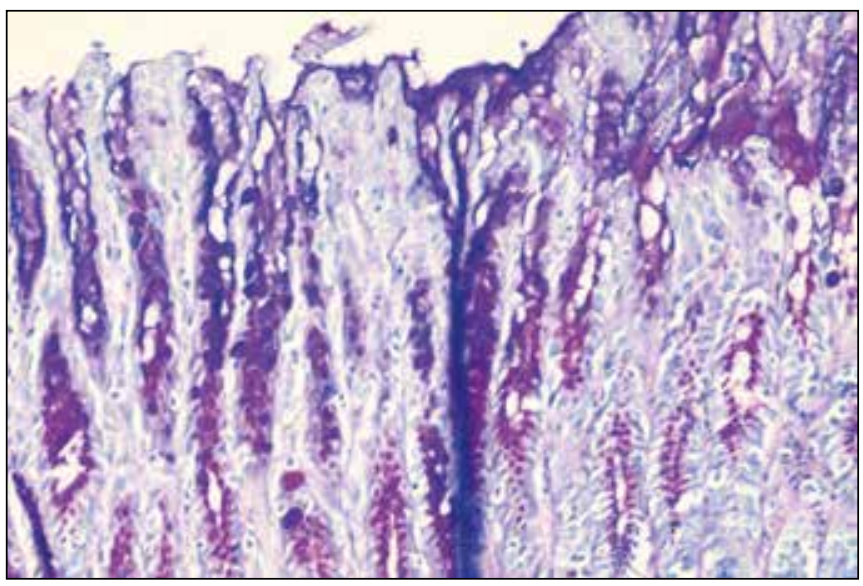

Fig. 9. The appearance ofacidsialomucinsin the superficial epitheliocytes of rat'sGM. ASA + clopidogrel+pantoprazole, 14day. A combined PAS-reaction with alcian blue x 200 .

As of today, reliable trustworthy morphological criteria of NSAIDs gastropathies which enable to differentiate them from gastritis are absent.

One of the basic method of NSAIDs-gastropathies diagnostics is morphological one but, gastropathies have no specific signs. That is why the aim of the research was to find out the pathomorphological peculiarities of the gastric mucosa at early stage of prescription of both ASA and combined therapy of ASA and clopidogrel as well as to study the impact of pantoprazole on the gastric mucosa to optimize the prophylaxis and treatment of gastropathies induced by ASA and clopidogrel.

\section{THE AIM}

The aim was to characterize the morphological peculiarities of the gastric mucosa at early stage of prescription of acetylsalicylic acid (ASA) and clopidogrel as well as to study the impact of pantoprazole on the gastric mucosa to optimize the prophylaxis and treatment of gastropathies induced by ASA and clopidogrel. 
Table I. Apoptosis index of gastric epitheliocytes

\begin{tabular}{cc}
\hline Groups & Apoptosis index (\%) \\
\hline Control & $2,9 \pm 0,32$ \\
\hline ASA & $7,18 \pm 0,48^{* *}$ \\
\hline Clopidogrel & $4,6 \pm 0,61^{*}$ \\
\hline ASA+clopidogrel & $9,3 \pm 0,37^{* *}$ \\
\hline ASA+pantoprazole & $4,1 \pm 0,56$ \\
\hline Clopidogrel + pantoprazole & $3,5 \pm 0,42$ \\
\hline ASA+ clopidogrel + pantoprazole & $3,4 \pm 0,31$ \\
\hline
\end{tabular}

* $-p<0,05$ in comparison to control group;

** $-p<0,001$ in comparison to control group.

\section{MATERIALS AND METHODS}

The research was carried out at the Histology, Forensic Medicine and Law Department of Vinnytsya National Pirogov Memorial Medical University.

The experiments were performed on 77 non-linear white male rats with the average weight of 150-180 g. Depending on the aim of research, the animals were divided into 7 groups. 5 animals made the control group, while the rest 72 once were divided into 6 groups (12 animals in each).

1. Group ASA took acetylsalicylic acid in the dose of $6,8 \mathrm{mg} /$ $\mathrm{kg}$ of the body weight (translation for an adult $-75 \mathrm{mg}$ ).

2. Group got clopidogrel $8 \mathrm{mg} / \mathrm{kg}$ of the body weight (translation for an adult $-75 \mathrm{mg}$ ).

3. Group ASA + clopidogrel got clopidogrel $6,8 \mathrm{mg} / \mathrm{kg}$ of the body weight (translation for an adult $-75 \mathrm{mg}$ ).

4. Group ASA + pantoprazole received acid $6,8 \mathrm{mg} / \mathrm{kg}$ of the body weight + pantoprazole $3,6 \mathrm{mg} / \mathrm{kg}$ (translation for an adult $-40 \mathrm{mg}$ ).

5. Group clopidogrel + pantoprazole was given clopidogrel $6,8 \mathrm{mg} / \mathrm{kg}$ of the body weight and pantoprazole $3,6 \mathrm{mg} / \mathrm{kg}$.

6. Group ASA + clopidogrel + pantoprazole got acetylsalicylic acid $6,8 \mathrm{mg} / \mathrm{kg}$ of the body weight, clopidogrel 6,8 $\mathrm{mg} / \mathrm{kg}$ of the body weight and pantoprazole $3,6 \mathrm{mg} / \mathrm{kg}$. The doses and ways of introduction of the mentioned substances were selected according to their clinical application and translated in relation to rats after the recommendations given by [16].

The duration of the experimental research was 14 days. During the research all the animals were given a standard ration of vivarium; the eating pattern and water consumption were ad libitum. The drugs were introduced once in 24 hours intragastrally with the help of a metal probe per $1 \%$ of starch suspension.

The experimient was done according to the rules of humane treatment of experimental animals confirmed by the Bioethics Committee of Vinnytsya National Pirogov Memorial Medical University.

The animals were excluded from the experiment through the overdosing of thiopental anaesthesia. The material obtained (stomachs) were fixed in $10 \%$ neutral formalin and after commonly accepted processing paraffin blocks were made, of which, in turn, sections of 5-7 mkm thickness were produced of the fundal and antral parts of the stomach by 2 pieces respectively.
To define pathomorphological changes, general histological techniques were applied (staining with hematoxylin and eosin), while to identify acid and neutral glycoproteins histochemical techniques were used (staining with alcian blue in $\mathrm{pH} \mathrm{1,0}$ and 2,5 in combination with PAS-reaction) [1].

For the quantitative assessment of apoptotic cells' contents, the index of apoptosis (IA) was used, which was calculated in percents after the formula IA = the number of apoptotic cells/general number of all cells x 100 [17].

The immunohistochemical research was carried out on paraffin sections with the use of the streptavidin-biotin method («DAKO», Denmark, LSAB2 Systems, HRP).

A damasking of antigen was performed in the citrate buffer with $\mathrm{pH}$ 6,0. Mouse monoclonal antibodies as primary ones were used. The cells nuclei were additionally stained with Mayer's hematoxylin during 15-60 sec.

The expression of caspase- 3 was evaluated with the help of mouse monoclonal antibodies CPP32 (clone JHM62, «Novocastra», Great Britain). To identify the expression of CPP32, the semi-quantitative scale of the evaluation of staining intensity was employed: 0 (absent) - the absence of positive reaction in cells, 1 (weak) - up to $30 \%$ of cells which reacted positively, 2 (moderate) $-31-60 \%, 3$ (strong) $-60 \%$ and more of stained cells [18].

\section{RESULTS}

In visual microscopy of GM in the control group, gastric pits were placed closely to each other, were not profound, straight, covered with cylindrical epithelium with basally located oval nuclei; in this, 2-3 fundic glands'necks entered each gastric pit.

The fundic glands looked like compact groups divided by thin layers of connective tissue. Their lumens were narrow. In the structure of the fundic glands, 3 main parts of cellular elements were defined clearly enough: chief, parietal exocrinocytes and mucous neck cells (Fig. 1).

The groups of experimental animals, which received ASA + pantoprazole and clopidogrel + pantoprazole, were characterized by the preservation of the basement membrane, which was clearly eminent under the superficial epithelium around the glands and was attached by blood capillaries. 
The connective tissue of GM was denudated within a short extension in both the ASA and clopidogrel groups as well; microerosions formed mainly in the antral part (in $94 \%$ of experimental animals).

The bottom of microerosions contained swollen connective tissue. The subepithelial lamina propria was marked by minute diapedetic hemorrhages, while infiltration by single lymphocytes and plasma cells around the area of swelling was noticeable (Fig. 2).

The denudated connective tissue of the lamina propria of GM was just covered with a thin layer of mucosa, which was locally absent. It was well observed while using PAS-reaction in combination with alcian blue (Fig. 3).

Interestingly, in $42 \%$ experimental animals, both of the ASA and clopidogrel groups, we observed the focal lympho and-plasmocytic infiltration with admixtures of segmentonuclear leukocytes in the basal parts of GM on the border with the muscular lamina (Fig. 4) and the dissociation of parietal and chief exocrinocytes (Fig. 5).

Damage to the basement membrane of superficial epitheliocytes, which was poorly enough diagnosed while staining with hematoxyllin and eosin and was clearly revealed in using of PAS-reaction, became one of the characteristic features for the ASA and clopidogrel groups separately as well as for the ASA+ clopidogrel group (Fig. 6).

However, in the group of ASA + clopidogrel damage to basement membrane was revealed in $42 \%$ experimental animals as opposed to $25 \%$ of the ASA group and $10 \%$ of the clopidogrel group and was not observed in the groups which obtained ASA + pantoprazole, clopidogrel + pantoprazole and ASA + clopidogrel + pantoprazole.

It is known that the basement membrane of the epithelial cover is formed of proteins synthesised by epitheliocytes. In the situation described above, the focal absence of the GM basement membrane epithelium can be connected to immaturity of epitheliocytes as a consequence of their accelerated death and regeneration which was confirmed by us in using caspase-3 (CPP32).

In particular, in the ASA group and the ASA + clopidogrel the number of positively stain cells made over $70 \%$ (fig. 7), while in the control group they made up to $10 \%$. The difference between the groups was reliable $(p<0,05)$.

While in the ASA + pantoprazole, clopidogrel + pantoprazole, ASA + clopidogrel + pantoprazole groups positively stained cells made $18 \%, 12 \%$ and $15 \%$ (fig. 8 ), respectively, the differences within the groups being unreliable $(\mathrm{p}>0,05)$.

In the ASA groups uperficial microerosions were observed in $25 \%$ of cases while in the ASA +clopidogrel group - in $42 \%$. However, in the clopidogrel group they were revealed just in $10 \%$ of the experimental animals.

After localization, microerosions, which dominated in the antral part (94\%), were observed. In the contol groups, ASA + pantoprazole, clopidogrel + pantoprazole, ASA + clopidogrel + pantoprazole erosions were not found.

Thus, in the ASA, clopidogrel and ASA + clopidogrel groups, homogenous changes in rats' GM and desquamation of superficial epitheliocytes were found. In this, the desquamation of superficial epitheliocytes with the breaking of the basement membrane integrity and formation of microerosions were revealed, degenerative disturbances being predominant. It was well revealed in using PAS-reaction with alcian blue.In the control group, the superficial epithelium had a highly prismatic form common to it and contained a large amount of secret.

At the same time, in the group of experimental animals, who received ASA + clopidogrel + pantoprazole with a higher frequency than that in the control one, different intensity of chief and parietal exocrinocytes staining was revealed. This probably depended on the different functional state of these glandular components. The number of acid sialomucins grew in superficial epitheliocytes as well (Fig. 9).

In the fundic part of the animals the superficial part of the GM preserved its usual structure but after the histochemical investigation in the most differentiated part and in the area of localization of the terminal parts somepeculiarities were determined.

Thus, in the group of clopidogrel the PAS-positive secrete granules in the chief cells were revealed. At the same time the cytoplasm of some chief cells lost its ability to stain and becomes cleared especially around the nucleus and between nucleus andthe basement membrane. The height of these cells decreases and nuclei become wrinkled with pyknosis.

The substantial difference in the distribution of mucus granules in the cytoplasm of superficial epitheliocytes in the ASA + pantoprazole, clopidogrel + pantoprazole, ASA + clopidogrel + pantoprazole was not not as well as in the control group.

Mucous neck cells of glands have less sizes than superficial epithelium and in the basal part of the latter the round nuclei were detected. The intensity of PAS-reaction with a homogeneous distribution of mucous secretion in these cells cytoplasm were smaller than in the superficial epithelium.

The structure of the other parts of the oxyntic and pyloric glands in the control group of animals and ASA + pantoprazole i clopidogrel + pantoprazole groups don't differ by any peculiarities when we use the conventional methods on the light level.

However, the essential decrease of epithelium secretory activity in the groups of ASA, clopidogrel and ASA + clopidogrel was revealed. In some areas adjacent to microerosions we detected even full lack of secretion. In that areas only remains of mucous substances (mainly acid glycoproteins) were observed using histhochemical method.

\section{DISCUSSION}

Thus, the pathomorphological changes in an erosive lesion of GM characterized by the mucins secretion disturbance of surface and foveolar epithelium, infiltration of lamina propria of GM by mononuclear cells and neutrophilic leucocytes and absence or small zone of fibrinoid necrosis. The disturbance of mucus secretion and glands destruction was associated with inflammatory infiltration in $19 \%$ of 
ASA + clopidogrel group, $15 \%$ of animals of ASA and $2 \%$ of clopidogrel group.

The same phenomena which almost related to the damage of glandular epithelium were found in the stomach antral part that was concerned more inflammation activity in particular this part of the stomach. In the clopidogrel group the glands surrounding erosion of GM for the most part preserved their normal structure and histochemical properties.

In the group of experimental animals that received the ASA the microerosions were as superficial epithelial defects with serous stoma swelling and cellular infiltrate (mainly neutrophilic leucocytes).

The field of fibrinoid necrosis was represented by unstructured weak eosinophilic PAS-positive masses with bord er parallel to surface of GM however they were observed only in $17 \%$ cases of ASA group and in $4 \%$ of the clopidogrel one.

From the direction of vascular bed the swelling of vascular walls and endotheliocytes with nuclei vacuolization, detachment of them into vessels lumen, increase permeability with perivascular edema, extravasates and plasmorrhagia was observed.

Thus, the histochemical data obtained by us suggest that administration of ASA, clopidogrel and combination thereof without prescription of concomitant Pantaprozole significantly decreased the synthesis of neutral glycoproteins and increased the synthesis of acid glycoproteins.

Blockage of enzyme systems of mitochondria epitheliocytes, which causes a disturbance of the processes of oxidative phosphorylation and leads to development of a cascade of non-fibrotic processes in cells, may be one of the important points in the pathogenesis of ASA and clopidogrel contact action. Inhibition of prostaglandin (PG) synthesis due to inhibition of cyclooxygenase (COX1) leads to a decreased secretion of the mucous gel, reduced secretion of bicarbonates, deterioration of GM blood supply, resulting in a disturbance of protective and reparative properties of its cells, which leads to emergence of erosions and ulcers. Probably, PG is a trigger mechanism for GM trophicity disorder, which leads to indurative changes and cellular destruction associated with onset of erosion $[3,19,20,21]$.

In addition, the medicines of this group have the ability to directly penetrate into the cells of the mucous membrane in the acidic gastric medium, breaking the mucosal-bicarbonate barrier and causing the inverse diffusion of hydrogen ions, thus damaging the cells of the envelope epithelium. Products of free-radical oxidation of lipids involved in damaging the mucous membrane of the stomach and destruction of mucopolysaccharides are formed as a result of ASA toxic effects. It has been proved that some NSAIDs can directly inhibit mucin synthesis and bicarbonate secretion, as chemical bond of these substances with gastric mucosal phospholipids reduces its hydrophobicity. NSAIDs influence the proliferation of epithelial cells, reducing the protective properties of the epithelium and the ability for adequate reparation $[22,23,24,25,26]$.
Pantoprazole supports the prevention of GM necrotic lesion by enhancing the protective properties of mucus. This phenomenon is caused by an increase of production of protective PGs, higher accessibility of sulfhydryl radicals, and reduced duration of antioxidant stress at GM level $[15,27,28,29]$.

During the apoptotic changes analysis of GM in different groups of animals the certain patterns were established. In particular in the control group the index of apoptosis to average $2,9 \pm 0,32 \%$ while in clopidogrel group it was $4,6 \pm 0,61 \%$, ASA $-7,18 \pm 0,48 \%$ and as much as possible the index of apoptosis was observed in ASA + clopidogrel $9,3 \pm 0,37 \%$ group (Table 1 ).

It should noted that the reliable differences of the apoptosis index in the control group when compared with clopidogrel $(\mathrm{p}<0,05)$, ASA $(\mathrm{p}<0,001)$ and ASA + clopidogrel groups $(\mathrm{p}<0,001)$.

The index of apoptosis was significantly lower in comparison to ASA and ASA + clopidogrel groups that pointing out less negative influence of clopidogrel on the GM in contrast to ASA and combination ASA + clopidogrel.

In clopidogrel + pantoprazole, ASA + pantoprazole and ASA + clopidogrel + pantoprazole groups the index of apoptosis amounts to $3,5 \pm 0,42 \%, 4,1 \pm 0,56 \%$ and $3,4 \pm 0,31 \%$ correspondingly. We don't establish the reliable differences these groups when compared to control group $(p>0,05)$. The differences were absent also when we make a comparison of the apoptosis index between clopidogrel + pantoprazole, ASA + pantoprazole abd ASA + clopidogrel + pantoprazole

By this line of reasoning, we conclude that pantoprazole has a positive effect on the GM epithelium during the clopidogrel, ASA antiplatelet pharmacotherapy performance as well as using of combination ASA with clopidogrel.

Thus, the problem remains relevant for safe using of ASA and clopidogrel and will demand the new searches and investigations in the future. The scientific searches directed to study of the blood circulation state, mechanisms of angionesis, balance of proliferation and apoptosis of gastric epitheliocytes, epidermal and transforming growth factors and deep understanding of molecular mechanisms enable to create the new derivatives of NSAIDs and antiaggregants targeted on certain elements of cells signal system.

\section{CONCLUSIONS}

1. According to our study findings, administration of ASA in combination with clopidogrel results in 2,5 times higher risk of GM erosive lesions.

2. One of the most significant morphological manifestations of gastropathy in ASA and clopidogrel regimen is the development of microerosions, which are poorly diagnosed by macroscopic examination.

3. The use of PAS-reaction makes possible to identify damage to the basal membrane of superficial epitheliocytes, which may be a top-priority morphological criterion of gastropathy induced by ASA or clopidogrel in the absence of an inflammatory reaction. 
4. Administration of pantoprazole in combination with ASA and clopidogrel contributes to preventing GM necrotic lesions by amplification of protective properties of mucus and stabilization of apoptotic activity of gastric epithelial cells.

Further study and regard to risk factors of development of gastropathy associated with administration of ASA and clopidogrel will provide an opportunity to significantly reduce the incidence of gastroduodenal complications and improve the expected effects of the above medicines.

\section{REFERENCES}

1. Lanas A., Garcia-Rodriguez L.A., Arroyo M.T. et al.:Effect of antisecretory drugs and nitrates on the risk of ulcer bleeding associated with nonsteroidal anti-inflammatory drugs, antiplatelet agents, and anticoagulants. Am J Gastroentero. 2007;102:507-15.

2. Lim Yu. J., Lee J.S., Ku Ya. S., Hahm K.-B. Rescue strategies against nonsteroidal anti-inflammatory drug-induced gastroduodenal damage J. Gastroenterol. Hepatol. 2009; 24:1169-1178.

3. Roth S.H. NSAID-gastropaty Arch Intern. Med. 1986;146:1075-107.

4. Bubnova M.G. Aspirin v profilaktike aterotromboza i koronarnoy bolezni serdtsa [Aspirin in the prevention of atherothrombosis and coronary heart disease]. Russian Journal of Cardiology 2010;4(84):115-121.

5. Reuther L., Andersen S. Combination therapy with acetylsalicylic acid and non-aspirin nonsteroidal anti-inflammatory drugs Ugeskr.Laeger. 2006;27(13):1310-1314.

6. Tsaneva M., Tolekova A., llieva G. The relationship between resorption and the morphological changes in the gastric mucosa of rats after acute and chronic exposures to acetylsalicylic acid Eksp.Med.Morfol. 1994;32: 69-79.

7. Braunwald E., Antman E.M., Beasley J.W. et al. ACC AHA guideline update for the management of patients with unstable angina and nonST-segment elevation myocardial infarction-2002: Summary article: A report of the American College of Cardiology. American Heart Association Task Force on Practice Guidelines (Committee on the Management of Patients With Unstable Angina). Circulation. 2002;106:1893-900.

8. Zayratiants O.V. Kolobov S.V., Selezneva M.G. et al. Ostryye erozivnoyazvennyye gastroduodenalnyye porazheniya u bolnykh serdechnososudistymi zabolevaniyami [Acute erosive-ulcerative gastroduodenal lesions in patients with cardiovascular diseases]. Russian medical news. 2010;4;56-63. (In Russian).

9. Jorgensen T. Ulcer formation and histochemical changes in rat-stomach mucosa induced by acetylsalicylic acid Acta.Pathol.Microbiol.Scand.A. 1976;84(1):64-72.

10. Lichtenberger L.M., Zhou Y., Dial E.J., Raphael R.M. NSAID injury to the gastrointestinal track; evidence that NSAIDs interact with phospholipids to weaken hydrophobic surface barrier and induce formation of unstable pores in membranes. J. Pharm. Pharmacol. 2006;5:1421-8.

11. Hayat M.A. Handbook of Immunohistochemistry an in situ Hybridization of Human Carcinomas. Molecular Genetics, Gastrointestinal Carcinoma, and Ovarian Carcinoma. Elsevier Academic Press. 2006;4:564.

12. Chan F.K.L., The David Y. Graham Lecture: Use of Nonsteroidal Antiinflammatory Drugs in a COX-2 Restricted Environment Am J Gastroenterol. 2008;103:221-7.

13. Avtandilov G.G. Osnovy patologoanatomicheskoy praktiki. Rukovodstvo [Fundamentals of pathological practice. Manual] RMAPO. 1998;505 (In Russian).
14. Yeomans N., Lanas A., Labenz J. et al Efficacy of esomeprazole $(20 \mathrm{mg}$ once daily) for reducing the risk of gastroduodenal ulcers associated with continuous use of low-dose aspirin. Am. J. Gastroenterol. 2008;103:2465-2473.

15. Skrypnyk I.M., Maslova H.S. Kombinovana antysekretorna terapiia v likuvanni erozyvno-vyrazkovykh urazhen shlunkovo-kyshkovoho traktu u khvorykh na hostri leikemii [Combined antisecretory therapy in treathment of erosive-ulcerative lesions of gastro-intestinal tract in patients with acute leukemia] Modern medical technologies 2010;2;5155 (In Ukrainian).

16. Lanas A., Garcia-Rodriguez L.A., Arroyo M.T. et al. Risk of upper gastrointestinal ulcer bleeding associated with selective cyclooxygenase-2 inhibitors, traditional non-aspirin non-steroidal antiinflammatory drugs, aspirin and combinations. 2006;55:1731-8.

17. Fries J., Kristen N., Bennet M. et al. The rise and decline of nonsteroidal anti-inflammatory drag-associated gastropathy in rheumatoid arthritis. Arthritis Rheum 2004; 50:2433-2440.

18. Fedchenko S.N., Klimochkina E.M., Galuzina L.O. Kletochnoye obnovleniye i apoptoz epiteliotsitov zheludka krys v otsenke dinamiki gastroduodenalnykh porazheniy pri intoksikatsii toluolom [Cellular renewal and apoptosis of epithelial cells of the stomach of rats in the evaluation of the dynamics of gastroduodenal lesions during intoxication with toluene] Ukrainian medical almanac. 2011;14(2);215217. (In Russian).

19. Karateyev A.E. Vozmozhnost ispolzovaniya NPVP u bolnykh s ZhKT i kardiovaskulyarnymi faktorami riska. [The possibility of using NSAIDs in patients with gastrointestinal and cardiovascular risk factors] RMZh. 2009; 17(7); 495-503 (In Russian).

20. Vertkin A.L., Shamuilova M.M., Naumov A.V. et al. Ostryye porazheniya slizistoy obolochki verkhnikh otdelov zheludochno-kishechnogo trakta v obshchemeditsinskoy praktike [Acute lesions of the mucous membrane of the upper gastrointestinal tract in general medical practice] Medical Almanac. 2012;1;71-72. (In Russian).

21. Brzozowska I., Targosz A., Sliwowski Z. Healing of chronic gastric ulcers in diabetic rats treated with native aspirin, nitric oxide (NO)derivative of aspirin and cyclooxygenase (COX)-2 inhibitor J.Physiol. Pharmacol. 2004;55(4);773-90.

22. Obshchiye eticheskiye printsipy rabotys seksperimentalnymi zhivotnymi pri provedenii meditsinskikh i biologicheskikh issledovaniy / Nats. kongres z bioyetiki (Kiiiv 17-20 veresnya 2001). [General ethical principles of working with experimental animals in medical and biological research.] Journal of the Academy of Medical Sciences of Ukraine. 2001;7(4);814-816 (In Russian).

23. Akbarova D.S., Abdusamatova D.Z., Yakubov A.V. Sostoyaniye zashchitnogo slizistogo baryera zheludka pri sovmestnom primenenii indometatsina s enalaprilom. omeprazolom i famotidinom [The state of the protective mucosal barrier of the stomach when co-administration of indomethacin with enalapril, omeprazole and famotidine] Gastroenterology of St. Petersburg.2008;2-3;3 (In Russian).

24. Zapadnyuk I.P., Zapadnyuk V.I., Zakhariya E.A. i dr. Laboratornyye zhivotnyye. Razvedeniye. soderzhaniye. ispolzovaniye v eksperimente. [Laboratory animals. Dilution, maintenance, use in the experiment] 3rd ed., Pererab. and add. Kiev: Vishcha School, Main Publishing House. 1983:383. (In Russian).

25. Konturek P., Brzozowski T., Pierzchalski P. Activation of genes for spasmolytic peptide, transforming growth factor alpha and for cyclooxygenase (COX)- 1 and $\mathrm{COX}-2$ during gastric adaptation to aspirin damage in rats Aliment.Pharmacol.Ther. 1998; 12 (8):767-77. 
26. Prochazka E., Pötzi R., Ehringer H. Changes in stomach and duodenal mucosa caused by acetylsalicylic acid therapy Acta.Med. Austriaca. 1988;15(3):80-82.

27. Svintsytskyi A.S. Aktualni pytannia diahnostyky ta likuvannia hastropatii, zumovlenykh nesteroidnymy protyzapalnymy preparatamy [Topical issues of diagnosis and treatment of gastropathy caused by nonsteroidal anti-inflammatory drugs] Health of Ukraine 2007; 20 (1); 6-77. (In Ukrainian).

28. Svintsytskyi A. S., Katerenchuk I. P. Yarmola T. I. NPZP-hastropatii: mynule, sohodennia i maibutnie [NSAID-Gastropathy: Past, Present and Future] Modern medical technology 2010;2;95-100 (In Ukrainian).

29. Yeomans N., Hawkey C., Brailsford W. Gastroduodenal toxicity of low-dose acetylsalicylic acid: a comparison with non-steroidal antiinflammatory drugs Curr.Med.Res.0pin. 2009;25(11): 2785-93.

\section{ORCID and contributionship:}

Alla G. Yankovetska: 0000-0001-9348-5198 ${ }^{B, D}$

Serhii V. Vernyhorodskyi: 0000-0002-9314-8527 ${ }^{\text {A }}$

Iryna G. Paliy: 0000-0002-9874-6825 E,F

Serhii V. Zaika: 0000-0002-3954-4537 ${ }^{\mathrm{C}}$

\section{Conflict of interest:}

The Authors declare no conflict of interest.

\section{CORRESPONDING AUTHOR \\ Alla G. Yankovetska \\ National Pirogov Memorial Medical University \\ 27/56 0. Antonova st., 21034 Vinnytsya, Ukraine \\ tel: +380674316575 \\ e-mail:allayankovetska@gmail.com}

Received: 07.04 .2020

Accepted: 24.11 .2020

A - Work concept and design, B - Data collection and analysis, C - Responsibility for statistical analysis, D-Writing the article, $\mathbf{E}$-Critical review, $\mathbf{F}$ - Final approval of the article 